\title{
The Bed Nucleus Is a Neuroanatomical Substrate for the Anorectic Effect of Corticotropin-Releasing Factor and for Its Reversal by Nociceptin/Orphanin FQ
}

\author{
Roberto Ciccocioppo, ${ }^{1,2}$ Amalia Fedeli, ${ }^{1}$ Daina Economidou, ${ }^{1}$ Federica Policani, ${ }^{1}$ Friedbert Weiss, ${ }^{2}$ and Maurizio Massi ${ }^{1}$ \\ ${ }^{1}$ Department of Pharmacological Sciences and Experimental Medicine, University of Camerino, 62032 Camerino, Italy, and ${ }^{2}$ The Scripps Research Institute, \\ Department of Neuropharmacology, La Jolla, California 92037
}

\begin{abstract}
Nociceptin/orphanin FQ (N/OFQ), the endogenous ligand of the opioid N/OFQ receptor (NOP), possesses marked functional anti-stress and anti-corticotropin-releasing factor (CRF) actions. We have shown that intracerebroventricular injection of N/OFQ reverses the hypophagic effect induced by stress or by CRF given intracerebroventricularly. To shed new light on the mechanisms involved in the anti-CRF action of N/OFQ, we investigated the ability of N/OFQ to prevent CRF-induced anorexia after microinjection studies into brain areas of potential interest in the control of feeding behavior and coexpressing NOP and CRF receptors. These areas include the bed nucleus of the stria terminalis (BNST), the central amygdala (CeA), the locus ceruleus (LC), the ventromedial hypothalamus (VMH), the paraventricular nucleus $(\mathrm{PVN})$, and the dorsal raphe (DR). The results demonstrated that the anorectic effect of $0.04 \mathrm{nmol}$ of CRF per rat (200 ng per rat) given intracerebroventricularly is reversed by pretreatment with $0.01-0.21 \mathrm{nmol}$ of N/OFQ per rat (25-500 ng per rat) injected into the BNST but not into the CeA, LC, VMH, PVN, or DR. Microinjection of $0.01-0.02 \mathrm{nmol}$ of CRF per site (50-100 ng per site) into the BNST but not into the CeA or the LC induced marked anorexia in food-deprived rats. Pretreatment with $0.01-0.21 \mathrm{nmol}$ of N/OFQ per site (25-500 ng per site) into the BNST also blocked the anorectic action of $0.02 \mathrm{nmol}$ of CRF per site ( $100 \mathrm{ng}$ per site) given in the same area. Finally, intra-BNST microinjection of 0.01- $0.21 \mathrm{nmol}$ of N/OFQ per site (25-500 ng per site) did not modify food intake in either food-sated or food-deprived rats. These data demonstrate that the BNST is involved in the modulation of CRF-induced anorexia, which is prevented by activation of $\mathrm{N} / \mathrm{OFQ}$ receptors.
\end{abstract}

Key words: nociceptin; orphanin FQ; corticotropin-releasing factor; bed nucleus of the stria terminalis; stress; anorexia

\section{Introduction}

The corticotropin-releasing factor (CRF) system is a major modulator of integrated physiological responses to stress. At the hypothalamic-hypophyseal level, it exerts a potent stimulation of adrenocorticotrophic hormone (Vale et al., 1981). In addition, CRF is localized in various corticomesolimbic structures, such as the amygdala, the bed nucleus of the stria terminalis (BNST), and the septum, where it is thought to be involved in the integration of emotional responses to stress (Chalmers et al., 1995; Lovenberg et al., 1995). Finally, CRF neurons have been identified in a number of brainstem structures, in which they regulate the autonomic stress response (Valentino et al., 1991). Two types of CRF receptors, type $1\left(\mathrm{CRF}_{1}\right)$ and type $2\left(\mathrm{CRF}_{2}\right)$, have been identified. $\mathrm{CRF}_{1}$ receptors are expressed primarily in the medial septum, pituitary, cortex, cerebellum, hindbrain, and olfactory bulbs, whereas $\mathrm{CRF}_{2}$ receptors are found in the lateral septum, ventro-

\footnotetext{
Received June 6, 2003; revised Aug. 6, 2003; accepted Aug. 6, 2003.

This study was supported by National Institutes of Health-National Institute on Alcohol Abuse and Alcoholism Grant NIAAA 10531 (F.W.) and by Grant MIUR 2002 (M.M.). We thank Mike Arends for his assistance with manuscript preparation.

Correspondence should be addressed to Dr. Roberto Ciccocioppo, Department of Pharmacological Sciences and Experimental Medicine, University of Camerino, 62032 Camerino, Italy. E-mail: roberto.ciccocioppo@unicam.it. Copyright $\odot 2003$ Society for Neuroscience $\quad$ 2270-6474/03/239445-07\$15.00/0
}

medial hypothalamus (VMH), medial amygdala, paraventricular nucleus (PVN), and choroid plexus (Chalmers et al., 1995; Van Pett et al., 2000). Studies conducted in both humans and laboratory animals have demonstrated that dysregulation of the brain CRF system is implicated in a variety of psychiatric disorders, including depression, anxiety, anorexia, and drug abuse (Heim and Nemeroff, 1999; Heinrichs and Richard, 1999; Koob, 1999; Sarnyai et al., 2001).

Nociceptin/orphanin FQ (N/OFQ) is an opioid peptide structurally related to dynorphin A. It binds selectively to its receptor, referred to as the opioid N/OFQ receptor (NOP) (formerly opioid receptor-like-1) (Meunier et al., 1995; Reinscheid et al., 1995). N/OFQ has an effect opposite to that of CRF, and its administration results in the inhibition of several behaviors linked to psychological stress (Jenck et al., 1997, 2000; Griebel et al., 1999; Martin-Fardon et al., 2000; Ciccocioppo et al., 2001). In addition, it has been shown that, although devoid of affinity for CRF receptors (Jenck et al., 1997, 2000), both N/OFQ and the selective NOP receptor agonist Ro 64-6198 completely block the anorexic effect induced by stress or CRF (Ciccocioppo et al., 2001, 2002).

The mechanisms underlying the anti-stress effect of N/OFQ are as yet unknown. Therefore, the present study was undertaken to evaluate at functional and neuroanatomical levels the interac- 
tion between CRF and N/OFQ by investigating the effect of the coadministration of these two peptides in discrete brain areas.

The experiments were guided by two major strategies: (1) CRF-induced anorexia was studied because previous experiments demonstrated that this behavior is highly sensitive to reversal by N/OFQ (Ciccocioppo et al., 2001, 2002). (2) We sought to identify the site of interaction between CRF and N/OFQ; to this end, the BNST, the central amygdala (CeA), the locus ceruleus (LC), the VMH, the PVN, and the dorsal raphe (DR) were selected because these nuclei represent key sites in the modulation of feeding or the regulation of behaviors linked to stress, and because in these nuclei, the two peptides and their receptors are abundantly coexpressed (Valentino et al., 1991; Chalmers et al., 1995; Lovenberg et al., 1995; Sim and Childers, 1997; Ikeda et al., 1998; Neal et al., 1999a,b).

\section{Materials and Methods \\ Subjects}

Male Wistar rats (Charles River, Calco, Italy) that weighed 200-250 gm at the beginning of the experiments were used. The animals were individually housed in a room on a $12 \mathrm{hr}$ light/dark cycle (lights off at 6:00 P.M.) at constant temperature $\left(20-22^{\circ} \mathrm{C}\right)$ and humidity $\left(45-55^{\circ}\right)$. Rats were offered food pellets (4RF; Mucedola, Settimo Milanese, Italy) and tap water ad libitum and were handled once a day for 5 min during the first week after arrival. All procedures were conducted in adherence to the European Community Council Directive for Care and Use of Laboratory Animals.

\section{Drugs}

CRF (rat and human) was purchased from Bachem (Bubendorf, Switzerland). Nociceptin/orphanin FQ was synthesized at the Department of Pharmacological Sciences and Biotechnology Center (University of Ferrara, Ferrara, Italy). Peptides were dissolved in sterile isotonic saline and injected in a volume of $1.0 \mu \mathrm{l}$ per rat or $0.5 \mu \mathrm{l}$ per site into the lateral cerebroventricle or into the specific brain areas, respectively.

\section{Surgical procedures}

For intracranial surgery, rats were anesthetized by intramuscular injection of $100-150 \mu \mathrm{l}$ of a solution containing ketamine $(86.2 \mathrm{mg} / \mathrm{ml})$ and acepromazine $(1.3 \mathrm{mg} / \mathrm{ml})$ per 100 gm body weight. A guide cannula (0.65 mm outside diameter) for injections of CRF and N/OFQ was stereotaxically implanted and cemented to the skull. For cannula placements, the coordinates in millimeters with reference to bregma were as follows: intracerebroventricular: anteroposterior (AP), - 1.0; lateral (L), 1.8; ventral (V), 2.0; BNST: AP, $-0.2 ; \mathrm{L}, \pm 1.2 ; \mathrm{V}, 6.0 ; \mathrm{CeA}$ : AP, -1.8 ; , $\pm 3.9 ; \mathrm{V}, 7.0 ; \mathrm{VMH}: \mathrm{AP},-2.0 ; \mathrm{L}, 0.5 ; \mathrm{V}, 8.0 ; \mathrm{PVN}$ : AP, $-1.0 ; \mathrm{L}, 0.4 ; \mathrm{V}, 7.0$; DR: AP, $-7.6 ; \mathrm{L}, 2.2 ; \mathrm{V}, 5.0$, with an angle of $19^{\circ}$. LC coordinates (AP, $-0.3 ; \mathrm{L}, \pm 1.2 ; \mathrm{V}, 5.0)$ were taken from the interaural line. For the BNST, the CeA, the VMH, the PVN, and the LC, cannulas were implanted bilaterally. A single cannula was aimed at the left lateral cerebroventricle and the DR. CRF and N/OFQ were injected through a stainless-steel injector protruding beyond the cannula tip: $2.5 \mathrm{~mm}$ for the lateral ventricle; $1.2 \mathrm{~mm}$ for the BNST; $1.5 \mathrm{~mm}$ for the CeA, the PVN, and the VMH; 2.0 for the DR; and 1.4 for the LC. Coordinates were taken from Paxinos and Watson (1986) and adjusted for the body weight of the animals. Experiments began 1 week after surgery. Before the experiment, rats received two vehicle microinjections to habituate the animals to the drug administration procedure. After completion of the experiments, rats were killed and cannula placements were verified histologically.

\section{Experiments}

Effect of N/OFQ microinjections into the BNST, CeA, LC, VMH, PVN, or $D R$ on the anorectic effect of CRF given intracerebroventricularly. To evaluate the dose-response curve for the anorectic effect of CRF, in the first experiment, eight rats were deprived of food for $20 \mathrm{hr}$ and then injected intracerebroventricularly with CRF $(0.02,0.04$, or $0.21 \mathrm{nmol}$ per rat) or its vehicle. The drug was administered according to a Latin square design, and animals were given food ad libitum 20 min after the intracerebroven- tricular injection of CRF. Food and water consumption were measured after 30 and $60 \mathrm{~min}$.

The intermediate dose of $0.04 \mathrm{nmol}$ of CRF per rat was chosen to study the ability of N/OFQ to prevent the anorectic effect of intracerebroventricular CRF. For this purpose, one group of rats $(n=9)$ was implanted with one cannula aimed at the left lateral cerebroventricle for CRF injection, whereas the other two cannulas were aimed at the BNST for N/OFQ administration. The second group $(n=8)$ was prepared with one intracerebroventricular and two intra-CeA cannulas, and the third $(n=8)$, fourth $(n=8)$, fifth $(n=8)$, and sixth $(n=10)$ groups were implanted with one intracerebroventricular cannula; the other two cannulas were aimed bilaterally at the LC, the VMH, the PVN, or one cannula was aimed at the DR. The six groups of rats were deprived of food for $20 \mathrm{hr}$ and then treated with N/OFQ $(0.01,0.02$, or $0.21 \mathrm{nmol}$ per site $)$ or its vehicle into the targeted brain areas. After $10 \mathrm{~min}$, the rats received an intracerebroventricular injection of $0.042 \mathrm{nmol}$ of CRF or its vehicle. Rats were given food ad libitum $20 \mathrm{~min}$ after the CRF injection, and food and water intake were measured after 30 and $60 \mathrm{~min}$. Drug and vehicle injections were administered according to a Latin square design.

Effect of CRF on feeding after injection in to the BNST, the CeA, or the LC. In subsequent experiments, to provide additional insight into the mechanisms of interaction between CRF and N/OFQ, the other three groups of rats ( $n=7-8$ per group) were injected with CRF directly into the BNST, the CeA, or the LC, and its effect on food consumption was investigated. Animals were deprived of food for $20 \mathrm{hr}$ and then bilaterally injected into the brain area of interest with CRF ( 0.01 or $0.02 \mathrm{nmol}$ per site) or its vehicle. The drug was administered according to a Latin square design, and animals were given access to food $20 \mathrm{~min}$ after the injection of CRF. Food and water consumption were measured after 30 and $60 \mathrm{~min}$.

Effect of coadministration of N/OFQ and CRF into the BNST. To confirm that the BNST is the site of interaction between CRF and N/OFQ, in this experiment, a group of rats was injected with both peptides into this area. Specifically, rats deprived of food for $20 \mathrm{hr}(n=6)$ were injected with N/OFQ $(0.01,0.02$, or $0.21 \mathrm{nmol}$ per site) or its vehicle into the BNST. After $10 \mathrm{~min}$, animals received intra-BNST injections of 0.02 nmol per site of CRF or its vehicle. Rats were given food ad libitum $20 \mathrm{~min}$ after the CRF injection, and food and water intake were measured 30 and $60 \mathrm{~min}$ after injection. Intracranial injections of drugs and vehicles were administered according to a Latin square design.

Effect of intra-BNST administration of N/OFQ on food intake in fooddeprived rats and in rats feeding ad libitum. A previous study demonstrated that intracranial administration of N/OFQ can stimulate feeding per se, although at doses of $>1.5-2.5 \mathrm{nmol}$ per rat (Pomonis et al., 1996; Polidori et al., 2000). To confirm that inhibition of the hypophagic effect of CRF is not subsequent to the direct orexigenic action of N/OFQ, experiments were conducted to evaluate the effect of intra-BNST administration of the peptide on food consumption. For this experiment, one group of rats $(n=10)$ was deprived of food for $20 \mathrm{hr}$, whereas another group $(n=9)$ was tested under ad libitum feeding conditions. In these experiments, the BNST of the two groups of animals was injected with $\mathrm{N} / \mathrm{OFQ}(0.01,0.02$, or $0.21 \mu \mathrm{g}$ per site $)$ or its vehicle in a counterbalanced order. Food was made available $30 \mathrm{~min}$ after injections, and food intake was recorded after 30 and $60 \mathrm{~min}$.

\section{Statistical analysis}

Food consumption (grams per kilogram of animal body weight) was analyzed by two-way (treatment and time) ANOVA with repeated measurements. Post hoc comparisons were performed by a Newman-Keuls test. For statistical purposes, only data for which correct cannula placement was confirmed by histological analysis were used. Statistical significance was set at $p<0.05$.

\section{Results}

\section{Histology}

At the end of the experiments, rats were killed with $\mathrm{CO}_{2}$ and perfused transcardially with isotonic saline followed by $3 \%$ formalin. Brains were removed, stored in formalin, and subsequently sectioned into $30 \mu \mathrm{m}$ coronal sections using a cryostat. After staining with cresyl violet, sections were examined under a 


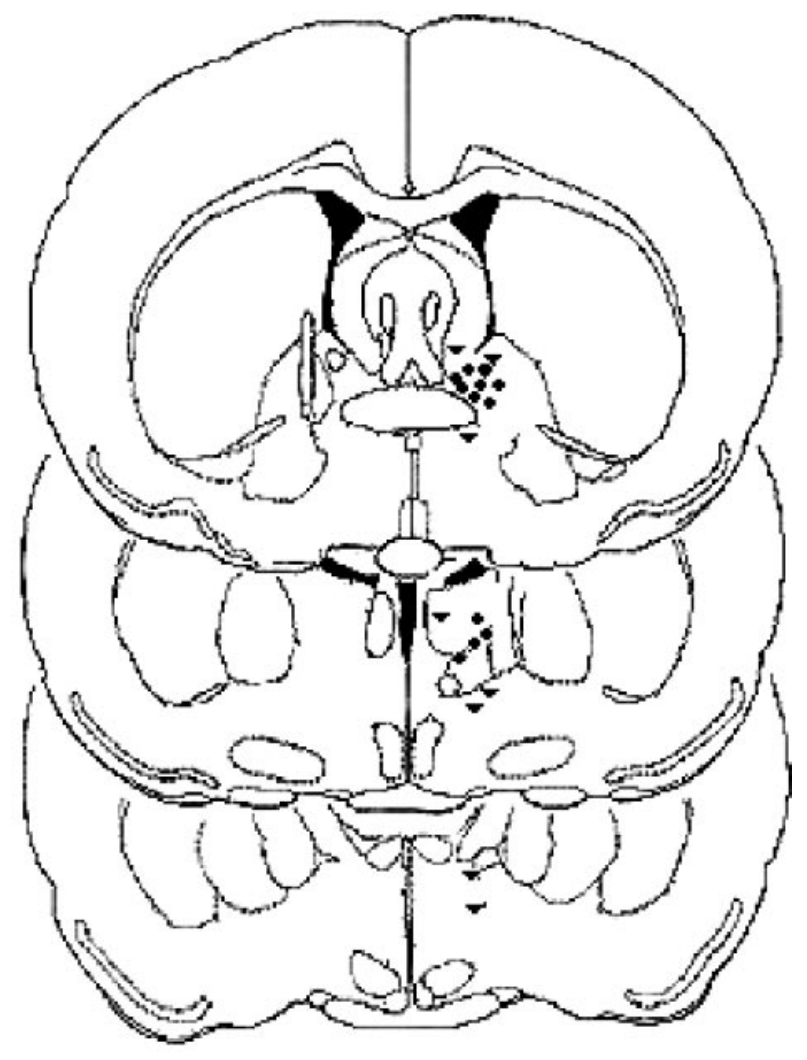

Figure 1. Histological reconstruction showing correct (filled circles) and incorrect (filled triangles) placements of cannula tips. Data presented in the figure are representative of only some of the animals used in the study and are indicative of the criteria used for identification of the correct injection sites. Drawing is from the atlas of Paxinos and Watson (1986).

microscope for the location of injector tip placement. An expert observer blind to treatment conditions and behavioral data was used for the histological verification. The analysis revealed that 97 of the 123 rats had injector tips placed in the expected brain sites. Correct cannula placements were found in 42 of 56 rats in the BNST (Fig. 1), 15 of 18 rats in the CeA, 14 of 19 rats in the LC, 8 of 10 rats in the VMH, 8 of 10 rats in the PVN, and 10 of 10 rats in the DR. Intracerebroventricular cannulas were in the correct position in all of the animals.

Effect of N/OFQ microinjections into the BNST, CeA, LC, VMH, PVN, or DR on the anorectic effect of CRF given intracerebroventricularly

Intracerebroventricular injection of CRF induced a marked reduction of food intake. ANOVA revealed an overall effect of treatment $\left(F_{(4,7)}=33.05 ; p<0.001\right)$. As shown by a NewmanKeuls test, this effect was statistically significant $(p<0.01)$ at all doses of CRF (Fig. 2). At the intermediate dose of $0.04 \mathrm{nmol}$ of CRF per rat, food intake was reduced by $\sim 40 \%$. This dose was subsequently used to study the effect of N/OFQ on CRF-induced anorexia. Experiments were conducted in water-sated rats that showed almost irrelevant water intake during the $1 \mathrm{hr}$ experiment (between $0.8 \pm 0.1$ and $1.4 \pm 0.3 \mathrm{ml} / \mathrm{kg}$ ). The ANOVA demonstrated that drinking was never affected by treatment (data not shown).

Microinfusion of N/OFQ into the BNST induced a complete reversal of the anorectic effect of CRF given intracerebroventricularly. Statistical analysis confirmed that intracerebroventric-

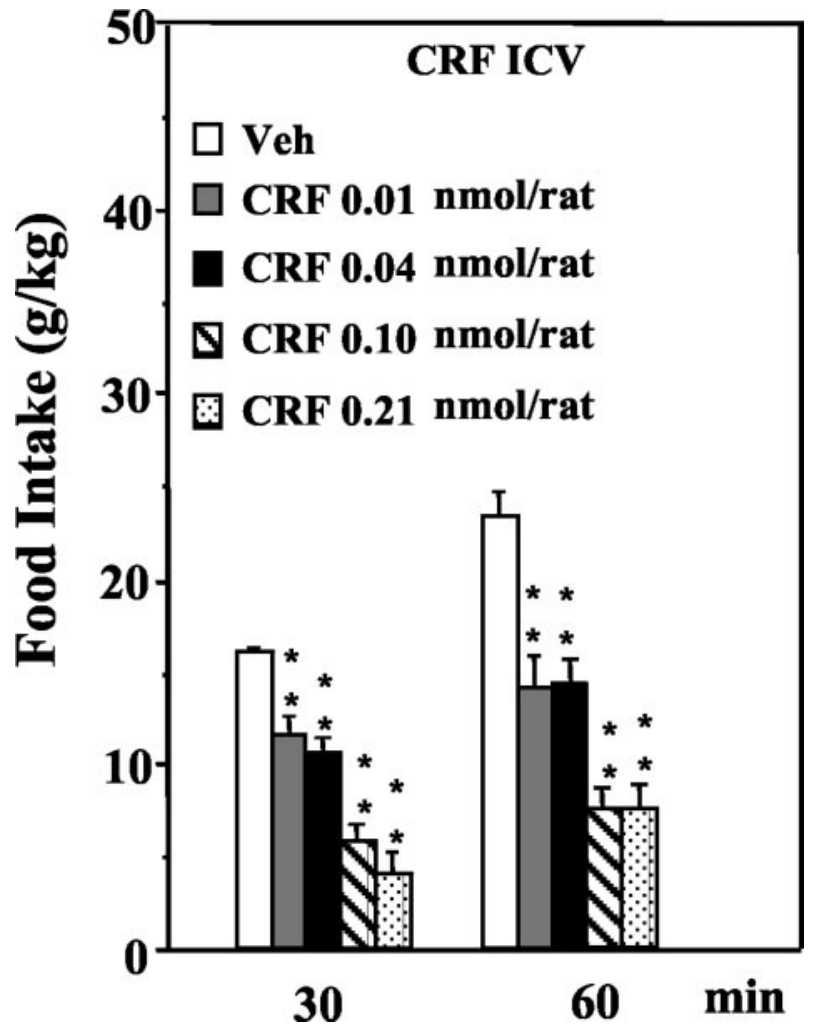

Figure 2. Effect of intracerebroventricular (ICV) CRF on food intake in rats deprived of food for $20 \mathrm{hr}$. Rats $(n=8)$ were injected intracerebroventricularly with $0.02,0.04,0.1$, or $0.21 \mathrm{nmol}$ of CRF or its vehicle (Veh) per rat. Access to food was given 20 min after CRF administration, and food intake was measured after 30 and $60 \mathrm{~min} .{ }^{* *} p<0.01$ versus control (Veh). Error bars represent SEM.

ular treatment with $0.04 \mathrm{nmol}$ of CRF per rat induced a significant inhibition of food intake. Pretreatment with N/OFQ into the BNST completely blocked the anorectic effect of CRF for the entire period (60 min) of observation $\left(F_{(4,8)}=6.99 ; p<0.001\right)$. As shown in Figure 3A, a Newman-Keuls test demonstrated a significant inhibition of food intake after intracerebroventricular microinfusion of $0.04 \mathrm{nmol}$ of CRF per rat $(p<0.01)$ that was completely reversed by intra-BNST administration of 0.02 and $0.21 \mathrm{nmol}$ per rat $(p<0.01)$ but not by $0.01 \mathrm{nmol}$ of N/OFQ per site. As shown in Figure $3 B-F$, microinfusion of the same doses of N/OFQ into the CeA, the LC, the PVN, the VMH, or the DR did not modify the anorectic effect of CRF given intracerebroventricularly. For all five brain areas, statistical analysis revealed an overall significant inhibition of feeding after intracerebroventricular $\operatorname{CRF}\left(F_{(4,7)}=5.47\right.$ and $p<0.01$ for the $\operatorname{CeA}, F_{(4,7)}=8.81$ and $p<0.01$ for the LC, $F_{(4,7)}=4.86$ and $p<0.01$ for the VMH, $F_{(4,7)}$ $=6.39$ and $p<0.01$ for the PVN, and $F_{(4,9)}=3.35$ and $p<0.05$ for the DR) that was not reversed by N/OFQ. The absence of effects of N/OFQ was confirmed by Newman-Keuls tests that demonstrated a significant difference between the control group (vehicle plus vehicle) compared with rats injected with intracerebroventricular CRF $(p<0.01)$ plus N/OFQ vehicle for all five brain areas. However, no differences were observed between rats injected intracerebroventricularly with CRF and N/OFQ vehicle and rats injected with intracerebroventricular CRF plus the different N/OFQ doses into the CeA, the LC, the VMH, the PVN, or the DR. Water intake was very low. ANOVA revealed no significant change in water consumption in all treatment groups (data not shown). 

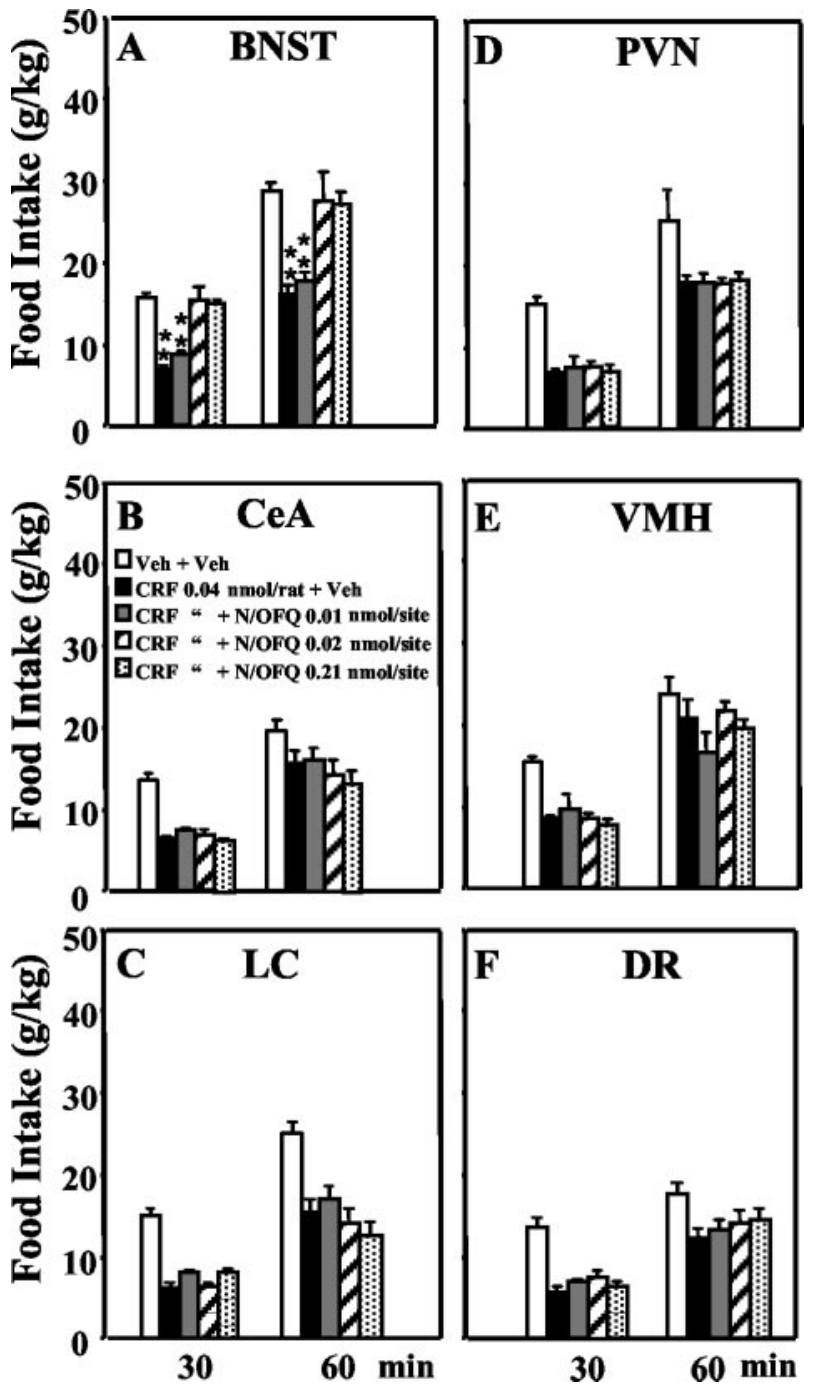

Figure 3. Effect of direct microinjections of N/OFQ in discrete brain areas on the inhibition of food intake after intracerebroventricular CRF administration in rats deprived of food for $20 \mathrm{hr}$. $A$, BNST of rats $(n=9)$ was injected with $0.01,0.02$, or $0.21 \mathrm{nmol}$ of N/OFQ or its vehicle (Veh) per site $10 \mathrm{~min}$ before injection of $0.04 \mathrm{nmol}$ of $(R F$ or its vehicle per rat intracerebroventricularly. CeA ( $B ; n=8$ rats), LC ( $C ; n=8$ rats), VMH ( $D ; n=8$ rats), PVN ( $E ; n=8$ rats), and DR ( $; ; n=$ 10) were injected with $0.01,0.02$, or $0.21 \mathrm{nmol}$ of $\mathrm{N} / 0 \mathrm{FQ}$ or its vehicle per site $10 \mathrm{~min}$ before 0.04 $\mathrm{nmol}$ of CRF or its vehicle per rat. Access to food was given $20 \mathrm{~min}$ after CRF administration, and food intake was measured after 30 and $60 \mathrm{~min}$. ${ }^{* *} p<0.01$ versus control (Veh + Veh). Error bars represent SEM.

Effect of CRF on feeding after injection into the BNST, the CeA, or the LC

After microinjection of CRF into the BNST, ANOVA revealed a marked inhibition of feeding $\left(F_{(2,7)}=7.61 ; p<0.01\right)$. For both time points (30 and $60 \mathrm{~min}$ ) the Newman-Keuls test revealed a significant $(p<0.01)$ effect of treatment (Fig. $4 A)$. In some animals (four rats) in which the cannula tips were found to be placed anterior to the BNST or in the posterior region of this nucleus, no effect of CRF was observed.

As shown in Figure $4 B, C$, when the same doses of CRF that were effective after intracerebroventricular or intra-BNST injection were given directly into the CeA or the LC, no effect of the peptide was observed. This was confirmed by statistical analysis that showed no change in food intake after either infusion of CRF into the CeA (Fig. $4 B)\left(F_{(2,6)}=0.33\right.$; NS) or the LC (Fig. $4 C$ ) $\left(F_{(2,6)}=0.22\right.$; NS). Water intake was very low in all animals.
Regardless of treatment condition, the ANOVA revealed no significant change in water consumption (data not shown).

Effect of coadministration of N/OFQ and CRF into the BNST Overall ANOVA demonstrated a significant effect of treatment $\left(F_{(4,5)}=7.93 ; p<0.01\right)$. As shown in Figure 5, the NewmanKeuls test demonstrated a significant inhibition of food intake after intra-BNST microinfusion of $0.04 \mathrm{nmol}$ per rat of CRF $(p<$ $0.01)$ that was completely reversed by pretreatment into the BNST with 0.02 and $0.21(p<0.01)$ but not $0.01 \mathrm{nmol}$ per site of N/OFQ. Also in this case, water intake was not modified by drug treatment (data not shown).

Effect of intra-BNST administration of N/OFQ on food intake in food-deprived rats and in rats feeding ad libitum

As shown in the previous experiments, food intake remained considerably high for the entire period $(60 \mathrm{~min})$ of observation in animals deprived of food for $20 \mathrm{hr}$. However, as shown in Table 1, statistical analysis demonstrated that administration of N/OFQ into the BNST at the same doses (0.01-0.21 nmol per site) that reversed the anorectic effect of CRF did not modify food consumption in this condition $\left(F_{(3,9)}=0.57\right.$; NS). As shown in Table 1 , at these doses, N/OFQ also was unable to modify food consumption in rats that were allowed to feed ad libitum $\left(F_{(3,8)}=\right.$ 0.04 ; NS); in these rats, baseline food intake was considerably lower compared with that of food-deprived animals. As in the previous experiments, water intake was recorded, and statistical analysis demonstrated that it was not modified by the drug treatment (data not shown).

\section{Discussion}

Reversal of CRF-induced anorexia by N/OFQ microinjection into the BNST

The major finding of this study was that CRF injected into the BNST produced marked hypophagia in food-deprived rats, and this effect was reversed by intra-BNST application of the opioidlike peptide N/OFQ. Previous work has demonstrated that the $\mathrm{VMH}$ and the PVN are important sites of action for the anorectic effect of stress and CRF (Ceccatelli et al., 1989; Kononen et al., 1992; Senba et al., 1993; Heinrichs and Richard, 1999; Timofeeva and Richard, 2001; Richard et al., 2002). However, microinjection experiments have shown that CRF and its analog urocortin significantly reduced food intake after intra-PVN and intraVMH administration only at doses of $\geq 0.5 \mu \mathrm{g}$ (Krahn et al., 1988; Ohata et al., 2000). In contrast, microinjection of CRF into the BNST in the present study suppressed food intake at substantially lower doses (0.01-0.02 nmol per site, which correspond to 0.05$0.1 \mu \mathrm{g}$ per site). This implicates the BNST as a key substrate in the regulation of CRF-induced anorexia.

N/OFQ administered into the BNST prevented the anorectic effect produced by both intracerebroventricular and intra-BNST application of CRF. N/OFQ did not block the hypophagic action of intracerebroventricular CRF after administration into the CeA, LC, VMH, PVN, or DR. Previous studies have demonstrated that N/OFQ possesses a hyperphagic effect per se, and that injection of the peptide into the VMH or into the arcuate nucleus stimulates basal feeding in rats (Stratford et al., 1997; Polidori et al., 2000). However, in the present experiments, we have shown that administration of N/OFQ into the BNST (at the same doses that antagonized CRF-induced hypophagia) did not alter food consumption in either food-sated or food-deprived rats. This suggests, therefore, that reversal of CRF-induced anorexia by 

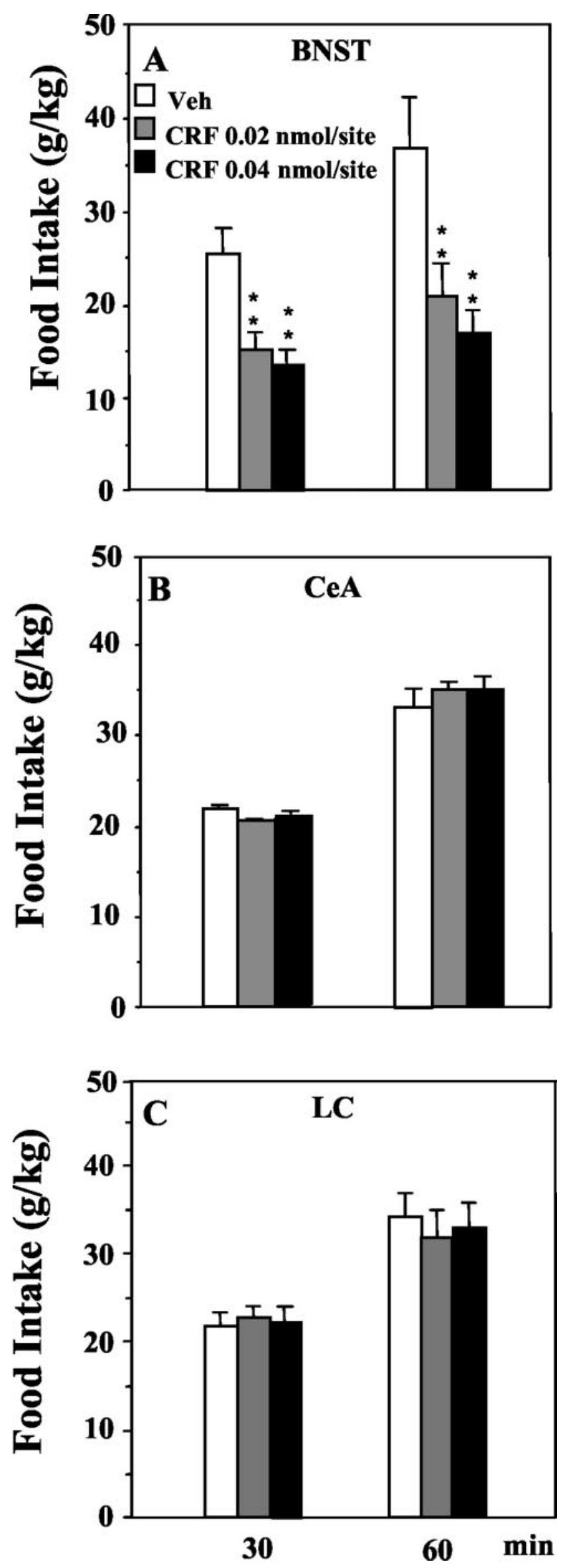

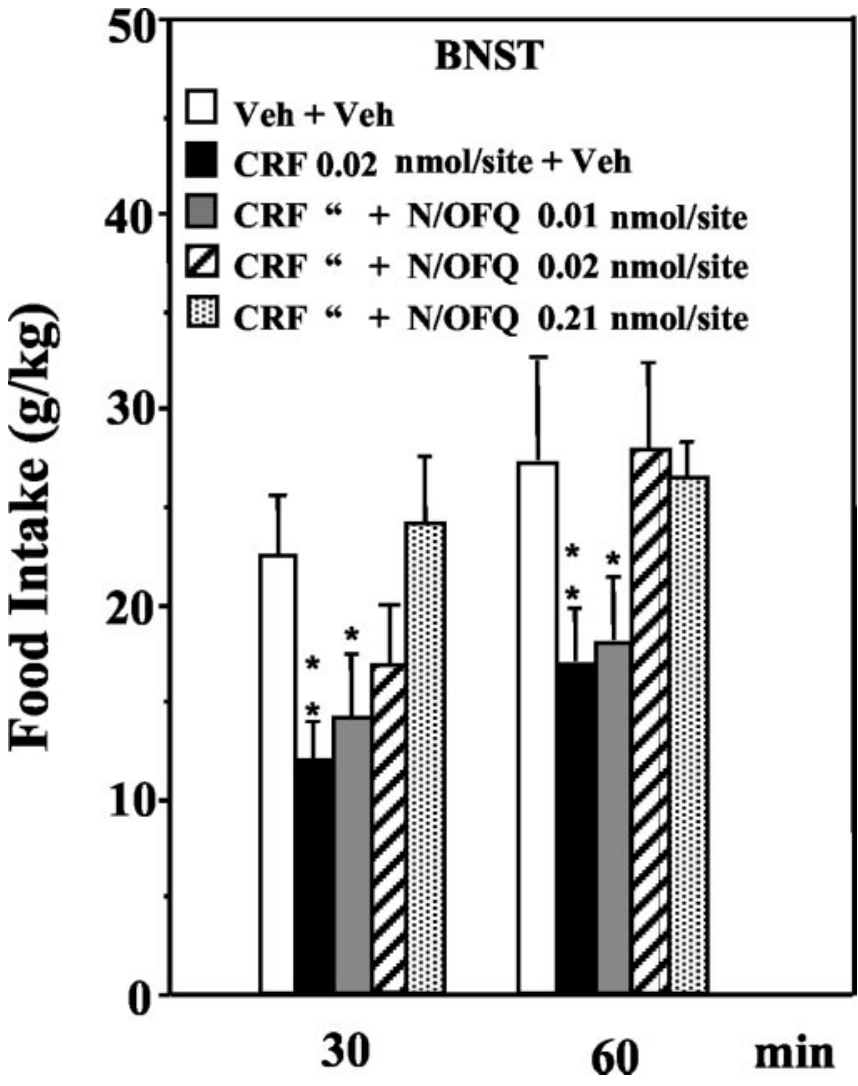

Figure 5. Effect of direct microinjections of N/OFQ and CRF into the BNST on food intake in rats deprived of food for $20 \mathrm{hr}$. BNSTs of rats $(n=6)$ were injected first with $0.01,0.02$, or 0.21 $\mathrm{nmol}$ of N/OFQ or its vehicle (Veh) per site. After $10 \mathrm{~min}$, animals received an intra-BNST injection of $0.02 \mathrm{nmol}$ of CRF or its vehicle per site. Access to food was given 20 min after CRF administration, and food intake was measured after 30 and 60 min. ${ }^{*} p<0.05$ and ${ }^{* *} p<0.01$ versus control (Veh + Veh). Error bars represent SEM.

$\mathrm{N} / \mathrm{OFQ}$ is independent of its modulatory effect on feeding behavior.

Evidence suggests that CRF neurotransmission in the CeA and in the BNST is linked to the regulation of various emotional aspects of stress, such as anxiety, fear responses, reinstatement of drug-seeking behavior, and modulation of drug withdrawal reactions (Lee and Davis, 1997; Erb et al., 1998; Erb and Stewart, 1999; Davis and Whalen, 2001; Sarnyai et al., 2001).

Interestingly, N/OFQ receptor stimulation reverses many of these behaviors. Namely, it reduces fear reactions, restraint, and foot-shock stress-induced anorexia and prevents stress-induced reinstatement of alcohol-seeking behavior (Jenck et al., 1997, 2000; Martin-Fardon et al., 2000; Ciccocioppo et al., 2001). Moreover, mice deficient for the N/OFQ gene consistently show high vulnerability to social stress, impaired adaptation to repeated stress, and, compared with wild-type controls, higher levels of basal and poststress plasma corticosterone (Koster et al., 1999).

Based on our understanding of the role of N/OFQ and CRF as well as on the function of the BNST in the regulation of stress

$\leftarrow$

Figure 4. Effect of direct microinjections of $(R F$ in discrete brain areas on food intake in rats deprived of food for $20 \mathrm{hr}$. BNSTs ( $A ; n=8$ rats), CeAs ( $B ; n=7$ rats), and LCs (C;n=7 rats) were injected with 0.01 or $0.02 \mathrm{nmol}$ of CRF or its vehicle (Veh) per site. Access to food was given 20 min after CRF administration, and food intake was measured after 30 and 60 min. ${ }^{* *} p<$ 0.01 versus control (Veh). Error bars represent SEM. 


\begin{tabular}{|c|c|c|c|c|}
\hline \multirow[b]{2}{*}{ N/OFQ } & \multicolumn{4}{|c|}{ Dose (nmol/site) } \\
\hline & 0.0 & 0.01 & 0.02 & 0.21 \\
\hline \multicolumn{5}{|l|}{ Food deprived } \\
\hline $\mathrm{t}(30 \mathrm{~min})$ & $13.4 \pm 0.5$ & $13.4 \pm 0.9$ & $14.5 \pm 0.7$ & $14.9 \pm 1.5$ \\
\hline $\mathrm{t}(60 \mathrm{~min})$ & $20.9 \pm 1.2$ & $22.1 \pm 1.3$ & $22.1 \pm 1.7$ & $22.2 \pm 2.9$ \\
\hline \multicolumn{5}{|l|}{ Food sated } \\
\hline t (30 min) & $0.3 \pm 0.2$ & $0.2 \pm 0.2$ & $0.2 \pm 0.2$ & $0.2 \pm 0.2$ \\
\hline$t(60 \mathrm{~min})$ & $0.3 \pm 0.2$ & $0.3 \pm 0.2$ & $0.3 \pm 0.2$ & $0.2 \pm 0.2$ \\
\hline
\end{tabular}

Access to food was given 30 min after N/OFQ injection, and food intake was measured after 30 and 60 min. Difference from controls was not significant. t, Time.

responses, one may speculate that in the BNST, these two systems may interact to regulate psychological aspects of stress-induced anorexia.

\section{Neuroanatomical and functional considerations}

Detailed neuroanatomical studies demonstrate that the BNST is composed of different subdivisions that receive afferents from different brain nuclei that give rise to distinct projections (Sun et al., 1991; Dong et al., 2001). Histological analysis of cannula placements in the present study demonstrated that in most of the animals, the cannula tips were located in the dorsal part of the anterior BNST. In this subregion of the BNST, a clear anorectic effect of CRF and its reversal by N/OFQ were evident. In one animal, the cannula reached the ventral portion of the anterior BNST. In this case, the animal did not respond to CRF. Finally, if cannulas were placed anterior to the BNST (two animals) or reached the terminal posterior portion of the BNST (two animals), no effect of CRF or N/OFQ was observed. Detailed investigation of the role of the various subdivisions of the BNST in CRF-induced anorexia was beyond the scope of the present study. However, considering the histological data, one may hypothesize that the site of action for the anorectic effect of CRF and its reversal by N/OFQ is the dorsal portion of the anterior BNST.

The dorsal part of the anterior BNST receives heavy projections from the central amygdala (Sun et al., 1991; Dong et al., 2001), including its medial portion, that are implicated in the regulation of psychological stress (Dayas et al., 2001; Dayas and Day 2002). Moreover, the BNST receives information from brain regions involved in cognitive functions, such as the infralimbic subdivision of the medial prefrontal cortex, as well as from gustatory and visceral sensory areas of the dysgranular insular cortex (Saper, 1982; Yasui et al., 1991; McDonald et al., 1999; Dong et al., 2001). In addition, the BNST, including its anterior subdivision, receives and sends projections to viscerosensory cell groups of the LC, the parabrachial nucleus, and the nucleus of the solitary tract (Moga et al., 1989; Van Bockstaele et al., 1998, 1999, 2001; Dong et al., 2001). Moreover, the anterior portion of the dorsal BNST sends projections to regions of the paraventricular hypothalamus through which it controls neuroendocrine function and hypothalamic-pituitary-adrenal axis activity (Herman et al., 1994). Finally, the BNST projects to other hypothalamic subregions (i.e., ventromedial hypothalamus) that play an essential role in the regulation of ingestive behavior (Risold and Swanson, 1997; Swanson, 2000).

The BNST, therefore, is a highly differentiated nucleus that receives inputs from cognitive, somatosensory (i.e., olfactory, gustatory), and viscerosensory regions, and, in turn, projects reentrant loops to these regions. Considering this neuroanatomical organization of the BNST, one may hypothesize that this nucleus may function as an important relay in which autonomic, emotional, and possibly neuroendocrine signals are integrated to regulate the expression of motivated behaviors such as feeding, reproduction, and defensive reactions. Indeed, functional studies have demonstrated that the BNST is directly involved in the regulation of sexual behavior, in "fight or flight" responses, and in the modulation of psychological responses to stress or withdrawal from drugs of abuse (Erb and Stewart, 1999; Macey et al., 2003).

This study extends present understanding of the function of the BNST by demonstrating that this nucleus is involved in the regulation of stress-induced inhibition of feeding. Moreover, the data demonstrate that the BNST represents an important site of action for the anorectic effect of CRF and for the anti-CRF actions of $\mathrm{N} / \mathrm{OFQ}$.

\section{References}

Ceccatelli S, Villar MJ, Goldstein M, Hokfelt T (1989) Expression of c-Fos immunoreactivity in transmitter-characterized neurons after stress. Proc Natl Acad Sci USA 86:9569-9573.

Chalmers DT, Lovenberg TW, De Souza EB (1995) Localization of novel corticotropin-releasing factor receptor (CRF2) mRNA expression to specific subcortical nuclei in rat brain: comparison with CRF1 receptor mRNA expression. J Neurosci 15:6340-6350.

Ciccocioppo R, Martin-Fardon R, Weiss F, Massi M (2001) Nociceptin/orphanin FQ inhibits stress- and CRF-induced anorexia in rats. NeuroReport 12:1145-1149.

Ciccocioppo R, Biondini M, Antonelli L, Wichmann J, Jenck F, Massi M (2002) Reversal of stress- and CRF-induced anorexia in rats by the synthetic nociceptin/orphanin FQ receptor agonist, Ro 64-6198. Psychopharmacology 161:113-119.

Davis M, Whalen PJ (2001) The amygdala: vigilance and emotion. Mol Psychiatry 6:13-34.

Dayas CV, Day TA (2002) Opposing roles for medial and central amygdala in the initiation of noradrenergic cell responses to a psychological stressor. Eur J Neurosci 15:1712-1718.

Dayas CV, Buller KM, Crane JW, Xu Y, Day TA (2001) Stressor categorization: acute physical and psychological stressors elicit distinctive recruitment patterns in the amygdala and in medullary noradrenergic cell groups. Eur J Neurosci 14:1143-1152.

Dong HW, Petrovich GD, Swanson LW (2001) Topography of projections from amygdala to bed nuclei of the stria terminalis. Brain Res Brain Res Rev 38:192-246.

Erb S, Stewart J (1999) The role for the bed nucleus of the stria terminalis, but not the amygdala, in the effects of corticotropin-releasing factor on stress-induced reinstatement of cocaine seeking. J Neurosci 19:RC35(1-6).

Erb S, Shaham Y, Stewart J (1998) The role of corticotropin-releasing factor and corticosterone in stress- and cocaine-induced relapse to cocaine seeking in rats. J Neurosci 18:5529-5536.

Griebel G, Perrault G, Sanger DJ (1999) Orphanin FQ, a novel neuropeptide with anti-stress-like activity. Brain Res 836:221-224.

Heim C, Nemeroff CB (1999) The impact of early adverse experiences on brain systems involved in the pathophysiology of anxiety and affective disorders. Biol Psychiatry 46:1509-1522.

Heinrichs SC, Richard D (1999) The role of corticotropin-releasing factor and urocortin in the modulation of ingestive behavior. Neuropeptides 33:350-359.

Herman JP, Cullinan WE, Watson SJ (1994) Involvement of the bed nucleus of the stria terminalis in tonic regulation of paraventricular hypothalamic CRH and AVP mRNA expression. J Neuroendocrinol 6:433-442.

Ikeda K, Watanabe M, Ichikawa T, Kobayashi T, Yano R, Kumanishi T (1998) Distribution of prepro-nociceptin/orphanin FQ mRNA and its receptor mRNA in developing and adult mouse central nervous systems. J Comp Neurol 399:139-151.

Jenck F, Moreau JL, Martin JR, Kilpatrick GJ, Reinscheid RK, Monsma Jr FJ, Nothacker HP, Civelli O (1997) Orphanin FQ acts as an anxiolytic to attenuate behavioral responses to stress. Proc Natl Acad Sci USA 94:14854-14858.

Jenck F, Ouagazzal AM, Pauly-Evers M, Moreau JL (2000) OrphaninFQ: 
role in behavioral fear responses and vulnerability to stress? Mol Psychiatry 5:572-574.

Kononen J, Honkaniemi J, Alho H, Koistinaho J, Iadarola M, Pelto-Huikko M (1992) Fos-like immunoreactivity in the rat hypothalamic-pituitary axis after immobilization stress. Endocrinology 130:3041-3047.

Koob GF (1999) Corticotropin-releasing factor, norepinephrine, and stress. Biol Psychiatry 46:1167-1180.

Koster A, Montkowski A, Schulz S, Stube EM, Knaudt K, Jenck F, Moreau JL, Nothacker HP, Civelli O, Reinscheid RK (1999) Targeted disruption of the orphanin $\mathrm{FQ} /$ nociceptin gene increases stress susceptibility and impairs stress adaptation in mice. Proc Natl Acad Sci USA 96:10444-10449.

Krahn DD, Gosnell BA, Levine AS, Morley JE (1988) Behavioral effects of corticotropin-releasing factor: localization and characterization of central effects. Brain Res 443:63-69.

Lee Y, Davis M (1997) Role of the hippocampus, the bed nucleus of the stria terminalis, and the amygdala in the excitatory effect of corticotropinreleasing hormone on the acoustic startle reflex. J Neurosci 17:6434-6446.

Lovenberg TW, Liaw CW, Grigoriadis DE, Clevenger W, Chalmers DT, De Souza EB, Oltersdorf T (1995) Cloning and characterization of a functionally distinct corticotropin-releasing factor receptor subtype from rat brain. Proc Natl Acad Sci USA 92:836-840.

Macey DJ, Smith HR, Nader MA, Porrino LJ (2003) Chronic cocaine selfadministration upregulates the norepinephrine transporter and alters functional activity in the bed nucleus of the stria terminalis of the rhesus monkey. J Neurosci 23:12-16.

Martin-Fardon R, Ciccocioppo R, Massi M, Weiss F (2000) Nociceptin prevents stress-induced ethanol- but not cocaine-seeking behavior in rats. NeuroReport 11:1939-1943.

McDonald AJ, Shammah-Lagnado SJ, Shi C, Davis M (1999) Cortical afferents to the extended amygdala. Ann NY Acad Sci 877:309-338.

Meunier JC, Mollereau C, Toll L, Suaudeau C, Moisand C, Alvinerie P, Butour JL, Guillemot JC, Ferrara P, Monsarrat B, Mazarguil H, Vassart G, Parmentier M, Costentin J (1995) Isolation and structure of the endogenous agonist of opioid receptor-like ORL1 receptor. Nature 377:532-535.

Moga MM, Saper CB, Gray TS (1989) Bed nucleus of the stria terminalis: cytoarchitecture, immunohistochemistry, and projection to the parabrachial nucleus in the rat. J Comp Neurol 283:315-332.

Neal Jr CR, Mansour A, Reinscheid R, Nothacker HP, Civelli O, Watson Jr SJ (1999a) Localization of orphanin FQ (nociceptin) peptide and messenger RNA in the central nervous system of the rat. J Comp Neurol 406:503-547.

Neal Jr CR, Mansour A, Reinscheid R, Nothacker HP, Civelli O, Akil H, Watson Jr SJ (1999b) Opioid receptor-like (ORL1) receptor distribution in the rat central nervous system: comparison of ORL1 receptor mRNA expression with ${ }^{125} \mathrm{I}-[(14) \mathrm{Tyr}]$-orphanin FQ binding. J Comp Neurol 412:563-605.

Ohata H, Suzuki K, Oki Y, Shibasaki T (2000) Urocortin in the ventromedial hypothalamic nucleus acts as an inhibitor of feeding behavior in rats. Brain Res 861:1-7.

Paxinos G, Watson C (1986) The rat brain in stereotaxic coordinates, Ed 2. North Ryde, Australia: Academic.

Polidori C, de Caro G, Massi M (2000) The hyperphagic effect of nociceptin/orphanin FQ in rats. Peptides 21:1051-1062.

Pomonis JD, Billington CJ, Levine AS (1996) Orphanin FQ, agonist of or- phan opioid receptor ORL1, stimulates feeding in rats. NeuroReport 8:369-371.

Reinscheid RK, Nothacker HP, Bourson A, Ardati A, Henningsen RA, Bunzow JR, Grandy DK, Langen H, Monsma Jr FJ, Civelli O (1995) Orphanin FQ: a neuropeptide that activates an opioid-like G-protein-coupled receptor. Science 270:792-794.

Richard D, Lin Q, Timofeeva E (2002) The corticotropin-releasing factor family of peptides and CRF receptors: their roles in the regulation of energy balance. Eur J Pharmacol 440:189-197.

Risold PY, Swanson LW (1997) Connections of the rat lateral septal complex. Brain Res Brain Res Rev 24:115-195.

Saper CB (1982) Convergence of autonomic and limbic connections in the insular cortex of the rat. J Comp Neurol 210:163-173.

Sarnyai Z, Shaham Y, Heinrichs SC (2001) The role of corticotropinreleasing factor in drug addiction. Pharmacol Rev 53:209-243.

Senba E, Matsunaga K, Tohyama M, Noguchi K (1993) Stress-induced c-fos expression in the rat brain: activation mechanism of sympathetic pathway. Brain Res Bull 31:329-344.

Sim LJ, Childers SR (1997) Anatomical distribution of mu, delta, and kappa opioid- and nociceptin/orphanin FQ-stimulated $\left[{ }^{35} \mathrm{~S}\right]$ guanylyl-5'-O(gamma-thio)-triphosphate binding in guinea pig brain. J Comp Neurol 386:562-572.

Stratford TR, Holahan MR, Kelley AE (1997) Injections of nociceptin into nucleus accumbens shell or ventromedial hypothalamic nucleus increase food intake. NeuroReport 8:423-426.

Sun N, Roberts L, Cassell MD (1991) Rat central amygdaloid nucleus projections to the bed nucleus of the stria terminalis. Brain Res Bull 27:651-662.

Swanson LW (2000) Cerebral hemisphere regulation of motivated behavior. Brain Res 886:113-164.

Timofeeva E, Richard D (2001) Activation of the central nervous system in obese Zucker rats during food deprivation. J Comp Neurol 441:71-89.

Vale W, Spiess J, Rivier C, Rivier J (1981) Characterization of a 41-residue ovine hypothalamic peptide that stimulates secretion of corticotropin and beta-endorphin. Science 213:1394-1397.

Valentino RJ, Page ME, Curtis AL (1991) Activation of noradrenergic locus coeruleus neurons by hemodynamic stress is due to local release of corticotropin-releasing factor. Brain Res 555:25-34.

Van Bockstaele EJ, Colago EE, Valentino RJ (1998) Amygdaloid corticotropin-releasing factor targets locus coeruleus dendrites: substrate for the coordination of emotional and cognitive limbs of the stress response. J Neuroendocrinol 10:743-757.

Van Bockstaele EJ, Peoples J, Valentino RJ (1999) Anatomic basis for differential regulation of the rostrolateral peri-locus coeruleus region by limbic afferents. Biol Psychiatry 46:1352-1363.

Van Bockstaele EJ, Bajic D, Proudfit H, Valentino RJ (2001) Topographic architecture of stress-related pathways targeting the noradrenergic locus coeruleus. Physiol Behav 73:273-283.

Van Pett K, Viau V, Bittencourt JC, Chan RK, Li HY, Arias C, Prins GS, Perrin M, Vale W, Sawchenko PE (2000) Distribution of mRNAs encoding CRF receptors in brain and pituitary of rat and mouse. J Comp Neurol 428:191-212.

Yasui Y, Breder CD, Saper CB, Cechetto DF (1991) Autonomic responses and efferent pathways from the insular cortex in the rat. J Comp Neurol 303:355-374. 